\title{
Effects of Motivational Factors on Employees Job Satisfaction \\ a Case Study of University of the Punjab, Pakistan
}

\author{
Ishfaq Ahmed (Corresponding author) \\ Hailey College of Commerce, University of the Punjab \\ Lahore, Pakistan \\ E-mail: ishfakahmed@gmail.com \\ Muhammad Musarrat Nawaz \\ Hailey College of Commerce, University of the Punjab \\ Lahore, Pakistan \\ E-mail: agoodperson101@yahoo.com \\ Naveed Iqbal \\ University of the Punjab Gujranwala Campus \\ Gujranwala, Pakistan \\ E-mail: naveediqbal81@yahoo.com \\ Imran Ali \\ Comsats Institute of Information Technology \\ Lahore, Pakistan \\ E-mail: imranalinim@gmail.com \\ Zeeshan Shaukat \\ Hailey College of Commerce, University of the Punjab \\ Lahore, Pakistan \\ E-mail: zeeshan.shaukat@gmail.com \\ Ahmad Usman \\ Hailey College of Commerce, University of the Punjab \\ Lahore, Pakistan \\ E-mail: a.usman@live.com
}

\begin{abstract}
Motivational factors play an important role in increasing employee job satisfaction. Satisfied employees in return can help in improving organizational performance. The objective of following research is to analyze the effects of motivational factors on job satisfaction of employees. This is an exploratory study based on primary data. The primary data has been collected from non-academic staff of University of the Punjab, which is one of the biggest universities of Pakistan. The study of Herzberg et al. (1959) has been widely validated and well renowned among research community. This theory tests hygiene and motivator factors and impact of personal and job characteristics on work perceptions and job satisfaction. Structural equation modeling technique has been applied to test hypothesis, SPSS 16.0 has also been adopted for basic analysis purposes. The results are being questionable to verify Herzberg's theory. The study concludes that intrinsic motivational factors are having significant relationship with employee job satisfaction, whereas hygiene
\end{abstract}


(extrinsic) factors are not having any significant relationship with employee job satisfaction. Moreover, significant difference was observed between gender, qualification, experience, job characteristics and job satisfaction. This study offers useful information as it provides both, the practical implications for professionals working on authoritative posts within Public Sector University set up in Pakistan, and theoretical implications for researchers interested in exploring job satisfaction in a higher education context.

Keywords: Motivation, Job performance, Organizational performance, Hygiene factors

\section{Introduction}

Many studies focusing on organizational behavior have given extensive consideration motivation, employee job satisfaction and organizational performance. All these variables are interdependent on each other.

Simply the association between motivation, job satisfaction and organizational performance can be viewed as: Motivation can be elaborated as what individuals strive to achieve better. However, not everyone gets motivated by the identical factors. Someone may get motivated by or satisfied by achieving higher authority and responsibility where some other person merely needs flexibility in work schedule, or someone may be motivated by sense of accomplishment.

When we talk about motivation this only effects people when they are ready for it and when it is applied the best way suitable for them. That is, when it feeds the needs of the person to be motivated. Still the motivation will not have effect on individuals if they are unable to perform a task or if they ar3e not willing for certain tasks. Here comes the role of leadership as leaders have to decide what foundation requirements are there to apply motivation and what sort of motivation is needed. Motivation is going to work if the right person with suitable skills is made responsible for the job or otherwise it will be a wastage of resources and time, and may lead to an opposite side that creates an incapable and non willing job performer.

This paper is aimed to study all those employees who are involved in administrative duties in the public sector university set up. These may include human resource professionals, financial professionals, IT experts and information department. This study is based on three basic questions that are, how job satisfaction is affected by personal characteristics and job characteristics? What are the paramount predictors the job satisfaction? And lastly verification of Herzberg's theory of motivators and hygiene factors. So the current research is not only to test the Herzberg's theory but to know about the quality of work life in university set up; so this research has both theoretical and practical perspectives.

\section{Conceptual Model and Development of Hypothesis}

Knowing job satisfaction requires study of great debates on this topic, one of the major contributories of this topic is Herzberg's theory of motivation. This paper starts with the review of Herzberg's theory of motivation and ends with the findings regarding job satisfaction in Public Sector University set up in Pakistan.

\subsection{Duality Theory of Job Satisfaction by Herzberg}

The debate on job satisfaction started when Herzberg published his book "THE MOTIVATION TO WORK” (1959). This book was based on interviews conducted with engineers and accountants. The respondents were asked to narrate a story about the event when they went exceptionally bad or exceptionally good. According to those situations he divided work dimensions in two elements Motivators and Hygiene factors. All those factors those caused exceptionally good feelings were motivators and satisfying factors; achievement, recognition, work itself, responsibility, advancement, and growth.

While recalling about the exceptionally bad events, they responded following points, administration of the company and its policy, supervisory behavior, relationship with superiors, working environment, salary, relationship with coworkers, relationships with subordinates, status, personal life, and safety measures. Herzberg narrated the above as Hygiene factors and related these events with external context of the work, and the motivators are going to deal with internal mind state. He compared his theory with traditional approach in motivation that assumes that salary, supervision or company policy leads employees towards higher job satisfaction. According to Herzberg job satisfaction is not through improving these 10 hygiene factors but by escalating the six motivators.

Moreover, an absence of the motivator factors will not cause job satisfaction e.g. when employees were not offered recognition or achievement or any other motivator for their work this will not cause the dissatisfaction of job yet they are not going to be motivated. The concept parallel to job satisfaction is not job dissatisfaction but no job satisfaction, and similarly opposite of job dissatisfaction is not job satisfaction but no job dissatisfaction.

Herzberg's theory was severely criticized and pointed out by various researchers, as Vroom (1964) this theory was making people uncovering themselves and making them good by attributing positive events to internal factors and negative events to external events. Even (1964) also criticized his work as he said that this theory was based on a limited job range and examined only one aspect of the job attitude, but if critical incident method of interviewing is followed and used findings support the duality (Herzberg's) theory of job satisfaction. 


\subsection{Job Satisfaction}

The concept and assessment of job satisfaction began in 1911 with the research of Taylor. Taylor (911) stated that rewards like the earnings of the job, incentive payments, promotion, appreciation, and opportunities for progress could lead to increased job satisfaction ( as cited by Aslan, 2001). Various researchers have defined the term job satisfaction. Wiener (1982) states that, job satisfaction is an attitude towards work-related conditions, facets, or aspects of the job. Feinstein (2000) was of the view that Job satisfaction is more of a response to a specific job or various aspects of the job.

Job satisfaction is an important element from organizational perspective, as it leads to higher organizational commitment of employees and high commitment leads to overall organizational success and development (Feinstein, 2000) additionally growth, effectiveness and efficiency of the organization and low employees' intentions to leave the organization (Mosadeghard 2000). Obstinately, dissatisfied individuals leave the organization and inflate the motivation of those staying there (Feinstein, 2000) and as a result workers loose performance and efficiency and might sabotage the work and leave the job (Sonmezer and Eryaman 2008).

Various researchers have contributed their research findings from organizational set ups, in order to increase employee job satisfaction and have given various suggestions to boost up the satisfaction. Feinstein (2000) says in order to increase individual's satisfaction level employees should be given advancement opportunities. Similarly changes in organizational variables, such as pay scales, employee input in policy development, and work environment could then be made in an effort to increase organizational commitment and overall outcome. Elton Mayo found that interaction within the group is the biggest satisfier. Safety, relation to work and success are followed by intergroup relations (Bektas, 2003). Mosadeghard (2000) gave Job satisfaction dimensions like nature of the job, management and supervision, task requirement, co-workers, job security, and recognition and promotion had more effect on employees' organizational commitment in organizational set up. Pensions and profit-sharing plans are positively associated with job satisfaction (Bender and Heywood, 2006). According to Stephen (2005), one would be wrong to consider one single measure of job satisfaction and there may be number of reasons that need to be considered (Stephen 2005). He further found that actual work was the biggest satisfier and working conditions were the least satisfier; job security was also big determinant of job satisfaction. Penn et al. (1988) found that opportunity for professional development is the biggest determinant to differentiate satisfied and non-satisfied employees. An employee will be satisfied if he has reached the ideals in his profession; he will develop positive feelings towards his profession (Sirin 2009).

Absence of work life balance, lack advancement opportunities, work environment, lack of encouragement, lack of recognition may lead to stress, which ultimately causes dissatisfaction, burnout and finally increased turnover rate within organization (Ahmadi and Alireza, 2007). Job satisfaction is inversely related to burnout, intentions to leave the organization (Penn et al. 1988). Job satisfaction is increased when income is greater than predicted income in education sector (Bender and Heywood, 2006).

\subsection{Job Satisfaction in University}

Hagedorn (1994) tested a causal model among faculty at different stages of career development and found that satisfaction with salary, total work hours, and co-workers support affected the level of stress and ultimately satisfaction. Increased freedom and flexibility of academicians would have resulted in significantly greater job satisfaction (Bender and Heywood, 2006). According to Sonmezer and Eryaman (2008) Salary, social status, advancement, ability utilization, administrative-employee relationship, creativity, security are the main factors that determine job satisfaction amongst education sector employees.

\section{INSERT FIGURE I HERE}

The job satisfaction research among administrative staff generally found satisfaction is best predicted by work stress caused by interpersonal relationships and the teamwork perceptions (Volkwein et al., 1998). They found that teamwork has a positive association with satisfaction and work stress caused by interpersonal relationships is negatively associated with satisfaction. Same results were witnessed by Volkwein \& Parmley (2000) when they studies administrative satisfaction and made a comparison between public sector and private sector universities. Element of teamwork, that are same as Herzberg's relationship with co-workers, is found to be positively associated with satisfaction confirming the theory of Herzberg's. Johnsrud \& Rosser (1999) conducted research on middle level managers and witnessed that perception of recognition, mobility, discrimination, and external relations, were the best explanatory variables of job satisfaction. Volkwein and Zhou (2003) found that organizational, environmental, and personal characteristics proved to be less influential than features such as teamwork, job security, and interpersonal relationship. They concluded that "overall satisfaction is the product of a complex balance of many ingredients".

In sum, none of the studies confirm or disconfirm Herzberg's duality theory. Almost all of the studies have concluded affects of either motivators or hygiene factors on job satisfaction. Smerek and Peterson (2006) used all elements of duality theory to testify the impact of all these factors over the satisfaction of administrative employees; and concluded 
that the work itself was the biggest predictor of job satisfaction amongst university administrative employees. This study is conducted to verify the findings of Smerek and Peterson's work in an underdeveloped countries set up with lack of resources and poor infrastructure.

The conceptual model was adopted from the research of Smerek and Peterson (2006) research work. This model contains personal characteristics, job characteristics, perceived work environment (intrinsic and extrinsic) and job satisfaction as major constructs of study (see Fig. I). Overall, the conceptual model frames the three research questions driving the study: How influential are personal characteristics and job characteristics on job satisfaction? What are the greatest predictors of job satisfaction? And is Herzberg's duality theory of motivators and hygiene factors verified in this higher education context? The following hypothesis can be developed based on previous discussions.

\section{Research Methodology}

\subsection{Instrument and Measurement}

This is an exploratory study based on primary data; the data has been collected through survey. The survey instrument was devised to assess all motivators and hygiene factors of Herzberg's theory. This questionnaire was based on all the elements of motivators and hygiene factors proposed by Herzberg et al (1959). Five point Likert scale was used ranging from 1 Strongly Disagree to 5 Strongly Agree. Personal demographic information was also collected in this survey and items were included in the survey, relevant items were also included to gather all necessary information.

\subsection{Population and Sampling}

This questionnaire was distributed amongst the administrative staff of university. The population of the study was 6,000 administrative staff member working in four campuses. Each campus has various institutes, schools, constituent colleges, departments and main administration department. This University offers bachelors and masters degrees in 16 disciplines; these are divided in 8 faculties. To limitize the scope of the study only one campus named as Quaid-e-Azam Campus was selected for study, as it is the main campus of the University. Out of this campus administrative staff of the 5 academic blocks; Hailey College of Commerce, Hailey College of Banking and Finance, Institute of Business Administration, Institute of Chemistry, Institute of Physics, and Center for High Energy Physics, were selected. These departments were selected because of their maximum number of students studying there and requirement of great number of administrative staff. There were five sections working in administration of these institutes i.e. Engineering, Examination, Medical, Registration and Treasury section. Out of these sections examination, Registration and Treasury sections were selected because of their scope of operation and greater number of employees working in these sections. The total strength of administrative staff working in these academic wings was 900 . Out of those total members 400 were selected for study using stratified random sampling technique. Out of those 312 responded back forming $78 \%$ $(\mathrm{n}=400)$ response rate.

\subsection{Data Analysis}

The main point in using SEM is to find the extent to which the model is 'fit' or effectively represents the sample data (Byrne, 2001). SEM is a statistical technique for testing and estimating causal relationships using a combination of statistical data and qualitative causal assumptions. This view of SEM was articulated by the geneticist Sewall Wright (1921), the economists Trygve (1943) and Herbert (1953), and formally defined by Judea (2000) using a calculus of counterfactuals. SEM normally starts with a hypothesis, develops it as a model, operationalises the constructs of interest with a measurement instrument, and tests the fit of the model to the obtained measurement data. Among the strengths of SEM is the ability to construct latent variables: variables which are not measured directly, but are estimated in the model from several measured variables each of which is predicted to 'tap into' the latent variables. This allows the modeler to explicitly capture the unreliability of measurement in the model, which in theory allows the structural relations between latent variables to be accurately estimated. Factor analysis, path analysis and regression all represent special cases of SEM.

\section{Results and Discussions}

The index fit of the model is shown in the table II. With (41.150) degree of freedom into consideration, most index values satisfy the general standard values for index fit. The general accepted standards for model fit are; Chi-square value (significant level $>0.05$ ), goodness of fit index (GFI > 0.80), adjusted GFI (AGFI > 0.80), normed fit index (NFI $>0.90)$, comparative fit index (CFI $>0.90$ ), and root means square residual $(\mathrm{RMR}<0.05)$. Although this model fit does not meet all standards, it may be overall an accepted model.

\section{INSERT TABLE II HERE}

Table III shows significant relationship between intrinsic motivational factors and employee job satisfaction. This is quite logical finding, it depicts that university administrative staff get motivated and higher job satisfaction by the recognition, work itself, opportunity for advancement, professional growth, responsibility, and good feelings about organization, therefore we accept our $\mathrm{H} 1$ hypothesis. We accept any hypothesis if the value of $\mathrm{p}$ is less than 0.05 . On the 
contrary, no significant relationship has been observed between hygiene (extrinsic) factors and employee job satisfaction. These factors includes effective senior management, effective supervisor, good relation with co-workers, satisfaction with salary, satisfaction with benefits, presence of core values, job security. These are interesting findings because employees do feel motivated by these factors and are not satisfied by these factors. These findings are having implication for the management of the university.

\section{INSERT TABLE III HERE}

Figure II depicts the results of SEM and also the nature of relationships between various variables. Positive relationship can be seen between intrinsic factors, hygiene (extrinsic) factors and employee job satisfaction.

\section{INSERT FIGURE II HERE}

Table IV explains the descriptive statistics of gender i.e. male and female. Table V shows the effects of gender on employee job satisfaction. T test has been applied to measure this association; Table V shows significant difference of gender on employee job satisfaction. Job satisfaction was significantly high in female employees than male employees.

\section{INSERT TABLE IV-VII HERE}

Kruskal-Wallis test has been applied to measure the effects of employee academic qualifications on job satisfaction. Table VI contains the results of Kruskal-Wallis Test. Table VII has applied Post Hoc Dunnett T3 test and shows significant relationship of academic qualification on employee job satisfaction. It was noted that job satisfaction was higher in employees with higher academic background i.e. master and above. The remaining categories of academic qualifications are having low effects on employee job satisfaction.

\section{INSERT TABLE VIII HERE}

Kruskal-Wallis test has been applied to measure the effects of employee work experience on job satisfaction. Table VIII contains the results of Kruskal-Wallis Test. Table IX has applied Post Hoc Dunnett T3 test and shows significant relationship of job experience on employee job satisfaction. It was noted that job satisfaction was higher in employees with work experience ranging from 5-10 years. The remaining categories of work experience are having low effects on employee job satisfaction.

Table X depicts that Kruskal-Wallis test has been applied to measure the effects of job characteristics (department) on job satisfaction. Table VIII contains the results of Kruskal-Wallis Test. Table XI has applied Post Hoc Dunnett T3 test and shows significant relationship of job characteristics on employee job satisfaction. It was noted that job satisfaction was higher in employees working in treasury department. Whereas the employees working in examination and registration departments are having low job satisfaction.

\section{INSERT TABLE VIII-XI HERE}

\section{Conclusion}

This study was conducted to test the Herzberg's motivation and hygiene theory in the context of non-academic staff of the University of the Punjab. In this regard it is an important study in the higher education set-up of Pakistan. The study concludes that significant relationship exists between intrinsic motivational factors including recognition; work itself, opportunity for advancement, professional growth, responsibility, good feeling about organization and employee job satisfaction. Whereas no significant relationship was found between hygiene (extrinsic) factors and employee job satisfaction. Moreover, higher job satisfaction was observed in employees of treasury department then employees of examination and student registration departments. Significant difference was noted regarding job satisfaction between male and female employees with female employees having more job satisfaction than male employees. There was no significant different of job satisfaction between permanent and temporary employees. Significant difference was found regarding employee academic qualification and job satisfaction, higher job satisfaction was noted in employees having higher education of master and above. Finally, significant difference was recorded regarding job experience ranging from 5-10 years; remaining categories of experience were having low job satisfaction.

This is an important study on motivation and job satisfaction in the context of higher education in Pakistan and it has implications for the management of higher education institutes and policy makers in higher education. This study also provided literature for future researchers on this topic.

\section{References}

Ahmadi K., and Alireza K. (2007). Stress and Job Satisfaction among Air Force Military Pilots. Journal of Social Sciences, 3(3), 159-163

Aslan, A.K. (2001). lkögretim I. kademe ögretmenlerinin yasam kalitesi ve mesleki doyumları. Ege Egitim Dergisi. 1(1):63-82

Bektas, H. (2003). Cs Doyum Düzeyi Farklı Olan Ögretmenlerin Psikolojik Belirtilerinin Karsılastırılması. 
Yayınlanmamıs yüksek lisans tezi, Atatürk Üniversitesi Sosyal Bilimler Enstitüsü, Erzurum: Türkiye

Bender, K. A., \& Heywood, J. S. (2006). Job satisfaction of highly educated. Scottish Journal of Political Economy, 53(2), 253-279.

Feinstein, A. H. (2000). A study of relationships between job satisfaction and organizational commitment among restaurant employees.

Hagedorn, L. S. (1994). Retirement proximity's role in the prediction of satisfaction in academe. Research in Higher Education, 35(6): 711-728.

Herbert, S. (1953). Causal ordering and identifiability, In: Hood, W.C. \& Koopmans, T. C., Studies in Econometric Method, Wiley, New York, pp. 49-74

Herzberg, F., Mausner, B., \& Snyderman, B. B. (1959). The Motivation to Work (2nd edition), John Wiley \& Sons, New York.

Johnsrud, L. K., \& Rosser, V. J. (1999). College and university mid-level administrators: Explaining and improving their morale. Review of Higher Education, 22(2), 121-141.

Judea, D. (2000). Causality: Models, Reasoning, and Inference. Cambridge University Press. England

Mosadeghard. (2008). A study of the relationship between job satisfaction, organizational commitment and turnover intention among hospital employees. Health Services Management Research, 21, 211-217.

Penn M., Romano J. L., and Foat D. (1988). The relationship between job satisfaction and burnout: a study of human service professionals. Administration in Mental Health, 15(3), 157-163.

Smerek, R. E., \& Peterson, M. (2006). Examining Herzberg’s Theory: improving job satisfaction among non-academic staff at a university. Research in Higher Education, 48(2), 229-250.

Stephen P. A. (2005). The job satisfaction of English academics and their intentions to quit academe. (viewed at http://129.3.20.41/eps/lab/papers/0512/0512005.pdf)

Sirin, A. F. (2009). Analysis of relationship between job satisfaction and attitude. Journal of Theory and Practice in Education, 5(1), 85-104

Sonmezer, M. G., \& Eryaman, M. Y. (2008). A comparative analysis of job satisfaction level of public and private school. Journal of Theory and Practice in Education, 4(2), 189-212

Vroom V. H. (1964). Work and motivation, Wiley Inc, New York

Volkwein, J. F., Malik, S. M., \& Napierski-Pranel, M. (1998). Administrative satisfaction and the regulatory climate at public universities. Research in Higher Education, 39(1), 43-63

Volkwein, J. F., \& Parmley, K. (2000). Comparing administrative satisfaction in public and private universities. Research in Higher Education, 41(1), 95-116

Volkwein, J. F., and Zhou, Y. (2003). Testing a model of administrative job satisfaction. Research in Higher Education, 44(2), 149-171

Wiener, Y. (1982). Commitment in organizations: A normative view. Academy of Management Review, 7(3):418-428.

Wright, S. S. (1921). Correlation of causation. Journal of Agricultural Research, 20: 557-85.

Table I. Development of Hypotheses

\begin{tabular}{|ll|}
\hline \multicolumn{2}{|c|}{ Hypotheses statements } \\
\hline H1 & Intrinsic motivation factors have positive influence on employee job satisfaction. \\
H2 & Extrinsic motivation factors have positive influence on employee job satisfaction. \\
\hline
\end{tabular}

Table II. Index of the fit of the Model

\begin{tabular}{|cccccccc|}
\hline Index of fit & Chi-Square (df) & P & GFI & AGFI & NFI & CFI & RMR \\
\hline Value & 33.426 & .000 & .891 & .346 & .396 & .380 & .052 \\
\hline
\end{tabular}


Table III. Regression Weights (results of hypotheses tests)

\begin{tabular}{|c|c|c|c|c|c|c|}
\hline Path & Estimates & S.E. & C.R. & P & Hypotheses & Results \\
\hline Intrinsic factors - Job Satisfaction & .207 & .039 & 5.297 & .000 & H 1 & Accept \\
\hline Extrinsic factors - Job Satisfaction & .060 & .038 & 1.564 & .118 & H 2 & Reject \\
\hline
\end{tabular}

Table IV. Gender and Job Satisfaction

\begin{tabular}{|c|c|c|c|c|c|}
\hline \multicolumn{7}{|c|}{ Group Statistics } \\
\hline \multirow{2}{*}{ Job Satisfaction } & Gender & $\mathrm{N}$ & Mean & Std. Deviation & Std. Error Mean \\
\cline { 2 - 6 } & Male & 377 & 1.1014 & .30282 & .02489 \\
\cline { 2 - 6 } & female & 23 & 1.0000 & .00000 & .00000 \\
\hline
\end{tabular}

Table V. Results of t-test

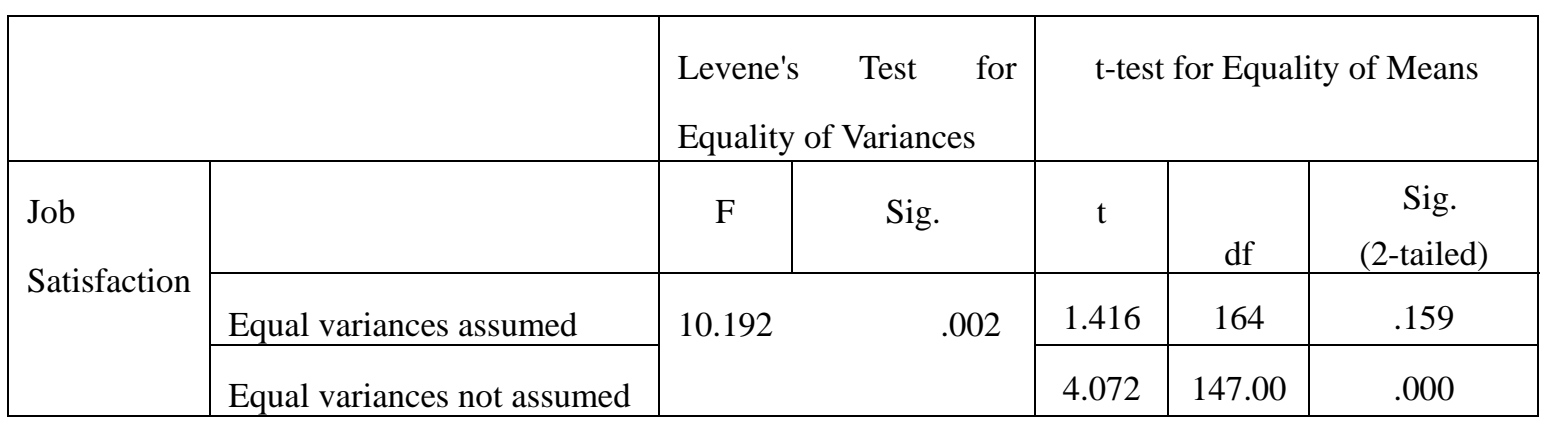

Table VI. Results of Kruskal-Wallis Test

\begin{tabular}{|c|c|c|c|}
\hline \multicolumn{4}{|c|}{ Ranks } \\
\hline \multirow{3}{*}{ Job Satisfaction } & Qualification & $\mathrm{N}$ & Mean Rank \\
\cline { 2 - 4 } & Masters and above & 158 & 94.86 \\
\cline { 2 - 4 } & Bachelors & 192 & 76.00 \\
\cline { 2 - 4 } & Intermediate & 36 & 76.00 \\
\cline { 2 - 4 } & Matric and below & 14 & 76.00 \\
\cline { 2 - 4 } & Total & 400 & \\
\hline
\end{tabular}


Table VII. Results of Post Hoc Tests

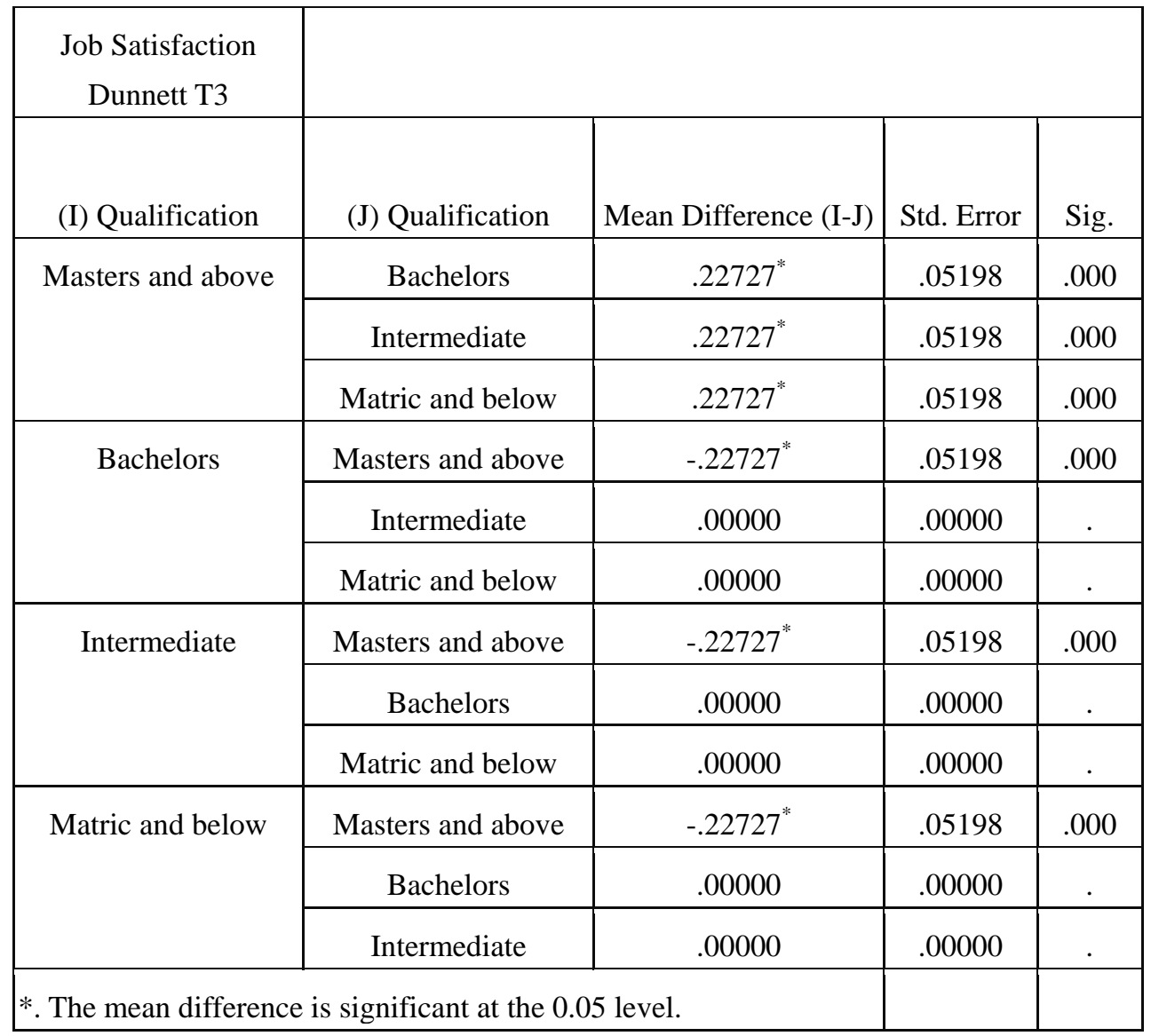

Table VIII. Results of Kruskal-Wallis Test

\begin{tabular}{|l|l|c|c|}
\hline \multicolumn{3}{|c|}{ Ranks } \\
\hline \multirow{4}{*}{ Job Satisfaction } & Work Experience & $\mathrm{N}$ & Mean Rank \\
\cline { 2 - 4 } & less then 5 years & 101 & 76.00 \\
\cline { 2 - 4 } & 5-10 years & 87 & 99.06 \\
\cline { 2 - 4 } & $10-15$ years & 29 & 76.00 \\
\cline { 2 - 4 } & $15-20$ years & 12 & 76.00 \\
\cline { 2 - 4 } & more then 20 years & 171 & 81.85 \\
\cline { 2 - 4 } & Total & 400 & \\
\hline
\end{tabular}


Table IX. Results of Post Hoc Tests

\begin{tabular}{|c|c|c|c|c|}
\hline $\begin{array}{c}\text { Job Satisfaction } \\
\text { Dunnett T3 }\end{array}$ & & & & \\
\hline (I) Work Experience & (J) Work Experience & Mean Difference (I-J) & Std. Error & Sig. \\
\hline \multirow[t]{4}{*}{ less then 5 years } & 5-10 years & $-.27778^{*}$ & .07571 & .008 \\
\hline & 10-15 years & .00000 & .00000 & . \\
\hline & $15-20$ years & .00000 & .00000 & . \\
\hline & more then 20 years & -.07042 & .03058 & .212 \\
\hline \multirow[t]{4}{*}{ 5-10 years } & less then 5 years & $.27778^{*}$ & .07571 & .008 \\
\hline & $10-15$ years & $.27778^{*}$ & .07571 & .008 \\
\hline & $15-20$ years & $.27778^{*}$ & .07571 & .008 \\
\hline & more then 20 years & .20736 & .08165 & .131 \\
\hline \multirow[t]{4}{*}{ 10-15 years } & less then 5 years & .00000 & .00000 & . \\
\hline & 5-10 years & $-.27778^{*}$ & .07571 & .008 \\
\hline & $15-20$ years & .00000 & .00000 & . \\
\hline & more then 20 years & -.07042 & .03058 & .212 \\
\hline \multirow[t]{4}{*}{$15-20$ years } & less then 5 years & .00000 & .00000 & . \\
\hline & 5-10 years & $-.27778^{*}$ & .07571 & .008 \\
\hline & $10-15$ years & .00000 & .00000 & . \\
\hline & more then 20 years & -.07042 & .03058 & .212 \\
\hline \multirow[t]{4}{*}{ more then 20 years } & less then 5 years & .07042 & .03058 & .212 \\
\hline & 5-10 years & -.20736 & .08165 & .131 \\
\hline & $10-15$ years & .07042 & .03058 & .212 \\
\hline & $15-20$ years & .07042 & .03058 & .212 \\
\hline
\end{tabular}

Table X. Results of Kruskal-Wallis Test

\begin{tabular}{|l|l|c|c|}
\hline \multicolumn{3}{|c|}{ Ranks } \\
\hline & Departments & N & Mean Rank \\
\hline \multirow{3}{*}{ Job Satisfaction } & examination & 189 & 81.32 \\
\cline { 2 - 4 } & Registration & 112 & 93.66 \\
\cline { 2 - 4 } & Treasury & 99 & 76.00 \\
\cline { 2 - 4 } & Total & 400 & \\
\hline
\end{tabular}


Table XI. Results of Post Hoc Tests

\begin{tabular}{|l|l|c|c|c|}
\hline $\begin{array}{l}\text { Job Satisfaction } \\
\text { Dunnett T3 }\end{array}$ & \multicolumn{2}{|l|}{} \\
\hline \multirow{2}{*}{ (I) Departments } & $(J)$ Departments & Mean Difference (I-J) & Std. Error & Sig. \\
\hline examination & Registration & -.14866 & .06649 & .083 \\
\cline { 2 - 5 } & Treasury & .06410 & .02791 & .071 \\
\hline \multirow{2}{*}{ Registration } & examination & .14866 & .06649 & .083 \\
\cline { 2 - 5 } & Treasury & $.21277^{*}$ & .06034 & .003 \\
\hline \multirow{2}{*}{ Treasury } & examination & -.06410 & .02791 & .071 \\
\cline { 2 - 5 } & Registration & $-.21277^{*}$ & .06034 & .003 \\
\hline \multirow{2}{*}{$*$ The mean difference is significant at the 0.05 level. } & & \\
\hline
\end{tabular}

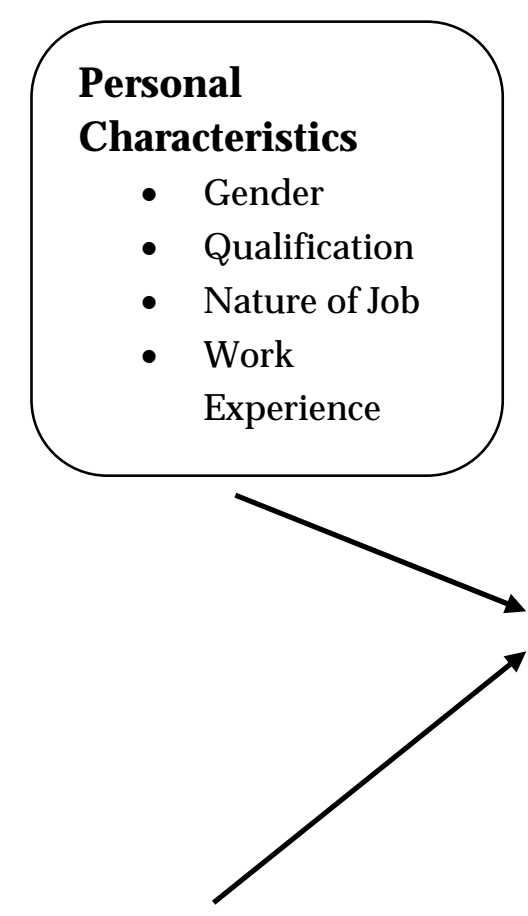

\section{Job Characteristics}

- Examination

- Treasury

- Registration

\section{Influence on}

work

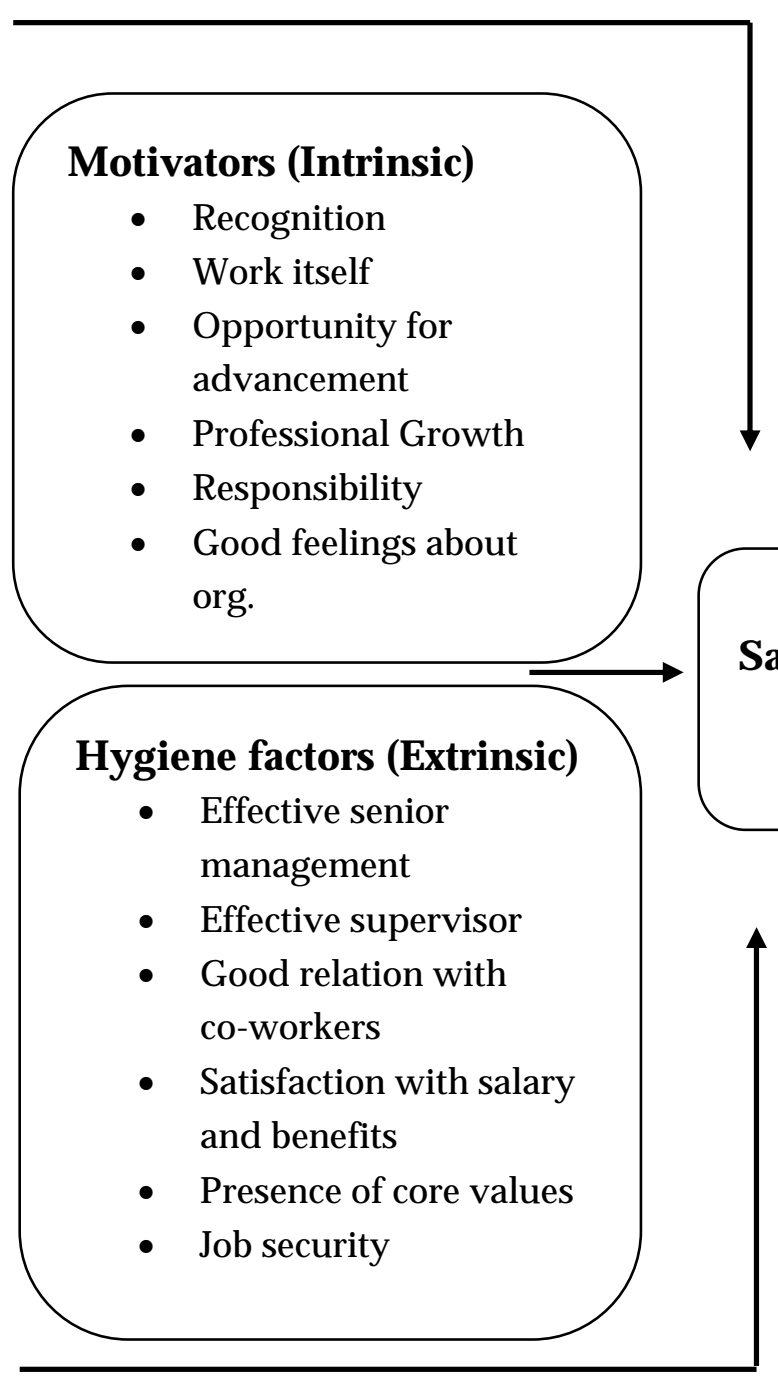

Perceived work
environment

\section{O utcome of work environment}

Figure I. Model for Assessing Job Satisfaction adopted from Semerek and Peterson (2008) 


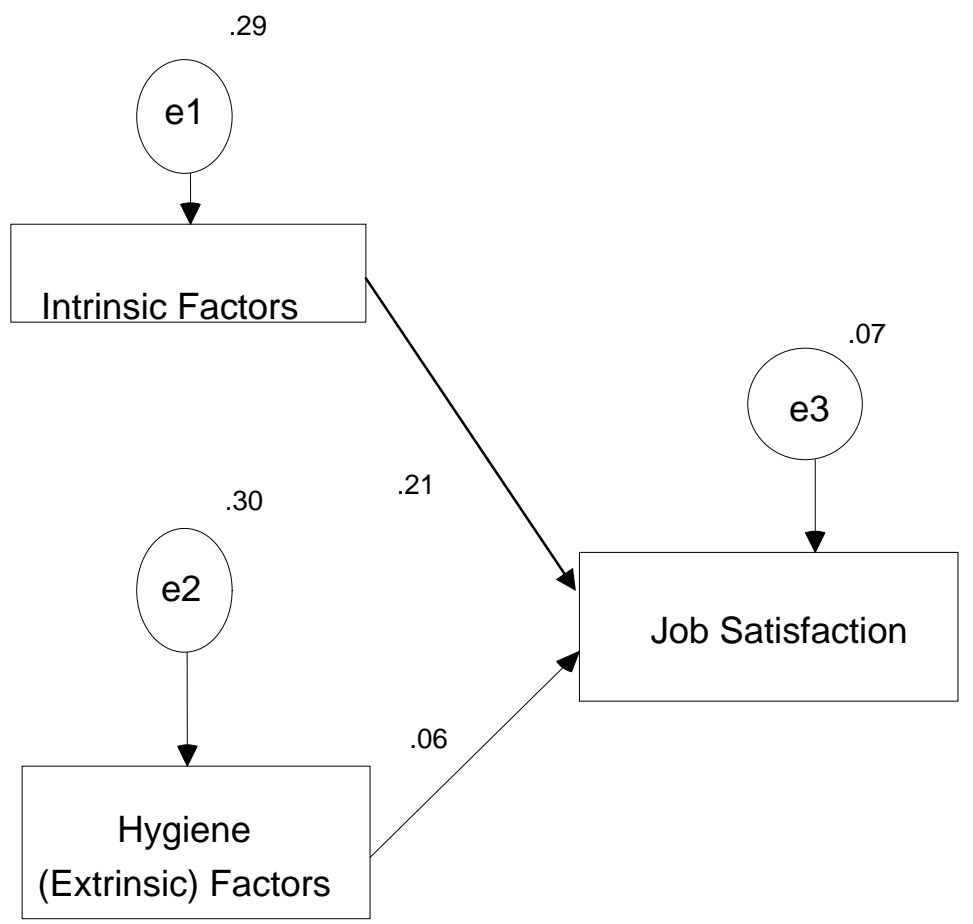

Figure II. AMOS Model 